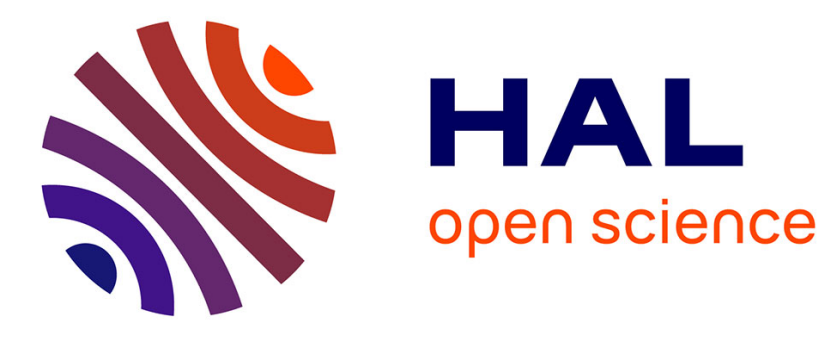

\title{
In Vivo and In Vitro Expression of Connexin 43 in Human Teeth
}

\author{
Imad About, Jean-Pierre Proust, Sylva Raffo, Thimios A Mitsiadis, \\ Jean-Claude Franquin
}

\section{- To cite this version:}

Imad About, Jean-Pierre Proust, Sylva Raffo, Thimios A Mitsiadis, Jean-Claude Franquin. In Vivo and In Vitro Expression of Connexin 43 in Human Teeth. Connective Tissue Research, 2009, 43 (2-3), pp.232-237. 10.1080/03008200290000952 . hal-03552366

\section{HAL Id: hal-03552366 https://hal.science/hal-03552366}

Submitted on 2 Feb 2022

HAL is a multi-disciplinary open access archive for the deposit and dissemination of scientific research documents, whether they are published or not. The documents may come from teaching and research institutions in France or abroad, or from public or private research centers.
L'archive ouverte pluridisciplinaire HAL, est destinée au dépôt et à la diffusion de documents scientifiques de niveau recherche, publiés ou non, émanant des établissements d'enseignement et de recherche français ou étrangers, des laboratoires publics ou privés. 


\title{
In Vivo and In Vitro Expression of Connexin 43 in Human Teeth
}

\author{
Imad About, Jean-Pierre Proust, Sylva Raffo, Thimios A. Mitsiadis, \\ and Jean-Claude Franquin \\ Laboratoire IMEB, Faculté d'Odontologie, Marseille, France
}

\begin{abstract}
Gap junctions are composed of transmembrane proteins belonging to the connexin family. These proteins permit the exchange of small regulatory molecules directly between cells for the control of growth, development and differentiation. Although the presence of gap junctions in teeth has been already evidenced, the involved connexins have not yet been identified in human species. Here, we examined the distribution of connexin $43(\mathrm{Cx} 43)$ in embryonic and permanent intact and carious human teeth. During tooth development, $\mathrm{Cx} 43$ localized both in epithelial and mesenchymal dental cells, correlated with cytodifferentiation gradients. In adult intact teeth, $\mathrm{Cx} 43$ was distributed in odontoblast processes. While Cx43 expression was downregulated in mature intact teeth, $\mathrm{Cx} 43$ appeared to be upregulated in odontoblasts facing carious lesions. In cultured pulp cells, $\mathrm{Cx} 43$ expression was related to the formation of mineralized nodules. These results indicate that $\mathrm{Cx} 43$ expression is developmentally regulated in human dental tissues, and suggest that $\mathrm{Cx} 43$ may participate in the processes of dentin formation and pathology.
\end{abstract}

Keywords Connexin 43, Carious, Human, Tooth, Development, Differentiation, Mineralization.

\section{INTRODUCTION}

Gap junctions are specialized regions of the cell membrane forming channels between neighboring cells. These channels permit the passage of ions and small molecules up to $1 \mathrm{kD}$ between cells $[1,2]$ and therefore direct cell-cell communication. In excitable tissues (i.e., heart muscle), gap junctions mediate a rapid propagation of electrical signals as well as synchronization of cell activity [3]. In nonexcitable tissues, gap junctions mediate the cell to cell traffic of metabolites and may carry signaling molecules for the control of cell growth and differentiation, as well as organ formation [4-10]. Gap junctions are composed

Received 19 June 2001; accepted 28 November 2001.

Address correspondence to Imad About, PhD, Laboratoire IMEB, Faculté d'Odontologie, 27 Boulevard Jean Moulin, 13385 Marseille, France. E-mail: imad.about@odontologie.univ-mrs.fr of transmembrane proteins that belong to the connexin family. Experimental studies have shown that the inhibition of gap junction communication with antibodies to connexins results in the disruption of embryonic development [5, 11]. Furthermore, mutation of the connexin 43 was lethal due to heart formation failure [12].

Tooth development is also under the control of signaling molecules: Sequential and reciprocal interactions between the epithelium and mesenchyme lead to the differentiation of mesenchymal cells into odontoblasts and epithelial cells into ameloblasts. Odontoblasts secrete the dentin matrix while ameloblasts synthesize enamel matrix [13-15]. Mineralization takes place at the late bell stage. A differentiation gradient is observed, where undifferentiated cells are located at the cervical loop area, while differentiated cells are located in the cusp area.

Gap junctions have been reported previously to be present during odontogenesis inside the enamel organ and dental mesenchyme, respectively [16-19]. Freeze fracture and electron microscopy studies in human teeth have revealed the presence of gap junctions between odontoblasts $[20,21]$ and between odontoblasts and subodontoblastic cells [22].

Connexin 43 is involved in the formation of gap junctions in the developing rodent teeth [23-25]. In addition to Cx43, connexin Cx32 and connexin Cx26 are expressed in epithelial dental cells and mature odontoblasts of rats, respectively [25].

However, the specific connexins involved in the formation of gap junctions between dental cells have not been systematically explored in human species. This work was carried out to investigate the expression of connexin 43 in human teeth under normal and pathological conditions.

\section{MATERIALS AND METHODS}

\section{Materials}

Embryonic Teeth

Teeth obtained from 17- and 22-week-old fetuses were collected from 10 medical inductions from the department of 
Anatomy and Pathology (Timone Hospital, Marseilles, France). The samples were obtained in agreement with the French ethical laws and after obtaining the ethical committee agreement. The gestation age was estimated from the fetal foot length and from the last menstruation of the mother. At each age, five central incisors, five canines, and five first molars were used.

\section{Permanent Teeth}

Teeth used in this study were (a) six third molars extracted during normal orthodontic treatment of adolescents (mean age $=$ $17 \pm 1$ years), and (b) six mature intact and six carious teeth (mean age $=40 \pm 2$ years).

\section{Antibodies and Reagents}

Anti Cx43 polyclonal antibodies were raised in rabbits against synthetic peptides and purified by affinity chromatography. These antibodies have been previously characterized [26-28] and cross-react with human tissues [26].

For the preparation of the culture media, materials were purchased from Gibco BRL (Life Technologies, Inc., Grand Island,
NY). Minimum essential medium (MEM) was supplemented with $10 \%$ fetal bovine serum, $2 \mathrm{mM}$ glutamine, $100 \mathrm{IU} / \mathrm{ml}$ penicillin, $100 \mu \mathrm{g} / \mathrm{ml}$ streptomycin (Biowhittaker, Gagny, France), and $0.25 \mu \mathrm{g} / \mathrm{ml}$ amphotericin B (Fungizone).

\section{Methods \\ Embryonic Teeth}

The teeth were immediately fixed at $4{ }^{\circ} \mathrm{C}$ for $1 \mathrm{~h}$ in $1 \%$ paraformaldehyde prepared in phosphate-buffered saline (PBS) (Sigma Chemical Co., St. Louis, MO). They were then dipped overnight at $4{ }^{\circ} \mathrm{C}$ in a $15 \%$ sucrose PBS solution. Samples were embedded in tissue-Tek O.C.T. compound (Miles, Elkhart, IN) and frozen over liquid nitrogen without prior decalcification. Serial cryostat sections (10 $\mu \mathrm{m}$ thick) were mounted on Superfrost Plus slides (CML, Nemours, France), dried at room temperature for $1 \mathrm{~h}$, then processed for indirect immunohistochemistry. Mayer's hematoxylin staining was performed on some sections for histologic examination.

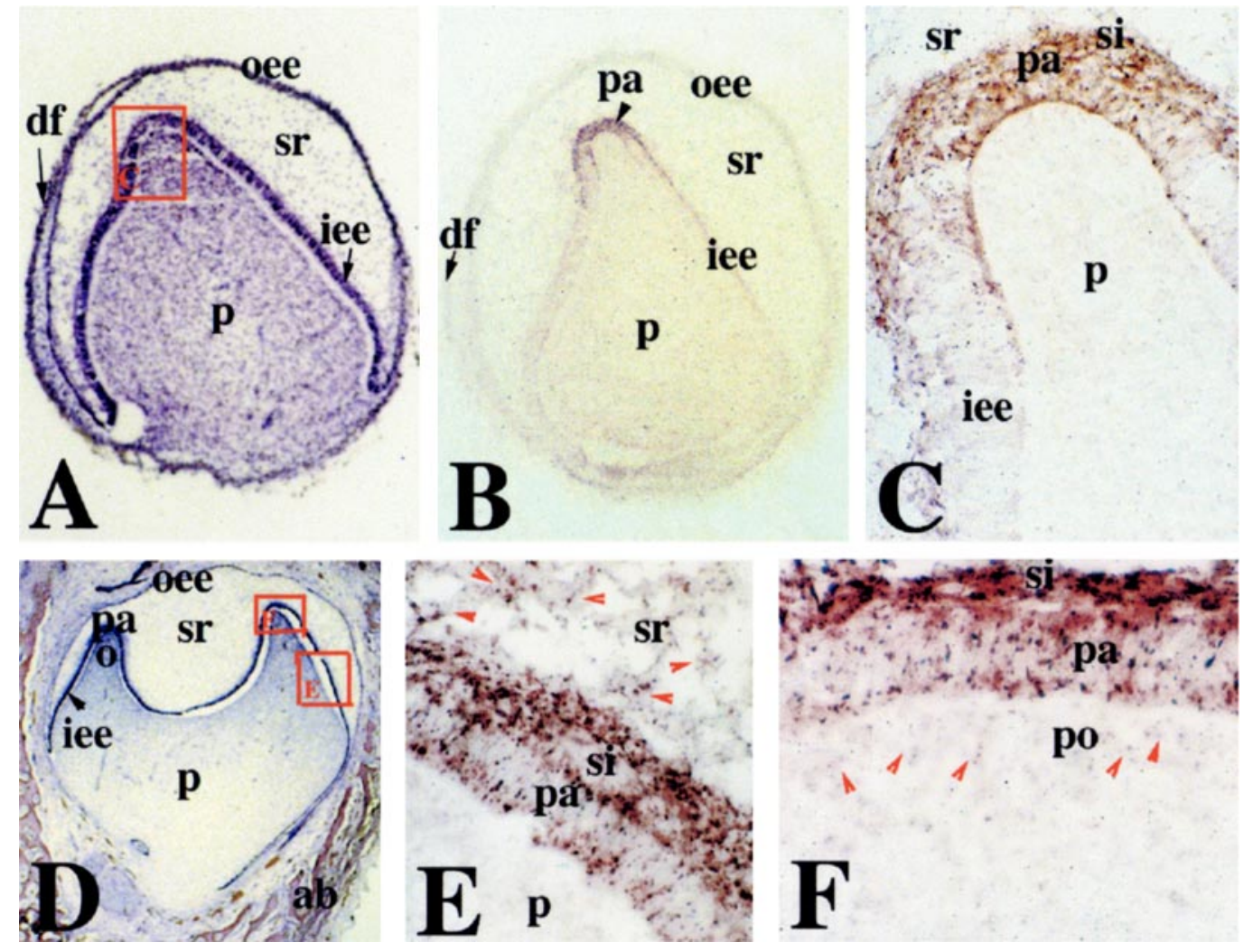

Figure 1. Immunohistochemical localization of $\mathrm{Cx} 43$ in embryonic human tooth germs at the bell stage of development: (A-C) Canine tooth germ of a 17-weekold embryo. (D-F) First molar tooth germ of a 22-week-old embryo. (A) Mayer's hematoxylin staining showing the different cell populations $(\times 4)$. The framed area represents the portion in (C). (B) A gradient of Cx43 immunostaining: Strong labeling is evident in preameloblasts (pa) and faint immunostaining is present in inner enamel epithelium (iee) and stellate reticulum (sr) cells $(\times 4)$. (C) Higher magnification of the cusp area showing the expression of Cx43 in preameloblasts and stratum intermedium (si) cells, $\times 40$. (D) Mayer's hematoxylin staining of a human first molar tooth germ at the bell stage $(\times 4)$. The frames indicate the sites of panels (E) and (F). (E) Strong Cx43 immunostaining is detected in preameloblasts, stratum intermedium, and stellate reticulum (arrowheads) cells, $\times 40$. (F) In the cusp area, weak Cx43 immunostaining is also found in preodontoblasts (po; arrowheads); $\times 60$. Abbreviations: iee, inner enamel epithelium; si, stratum intermedium; sr, stellate reticulum; oee, outer enamel epithelium; df, dental follicle; p, pulp; pa, preameloblast; po, preodontoblast; ab, alveolar bone. 


\section{Permanent Teeth}

After extraction, intact and carious teeth were fixed in $10 \%$ neutral buffered formalin for 7 days, demineralized in sodium formiate for 21 days, and then routinely processed and embedded in paraffin wax. They were then serially sectioned $(6-\mu \mathrm{m}$-thick sections) and processed for immunohistochemistry.

\section{Culture of Human Pulp Cells}

Cultures were performed as previously described [29]. Briefly, after the extraction, the teeth were swabbed with $70 \%(\mathrm{v} / \mathrm{v})$ alcohol and then washed with sterile PBS. They were then transferred into a laminar flow tissue culture hood in order to perform the rest of the procedures under sterile conditions. The apical part of the teeth was removed and the dental pulps were minced with scalpels and rinsed with PBS. Each dental pulp was divided into two groups: cultured without (control) or with $\beta$-glycerophosphate. In the control group, the explants were cultured in 100-mm-diameter culture dishes (Becton Dickinson Labware, Lincoln Park, NJ) in MEM medium. In the second group, the explants were cultured under the same conditions in the same medium supplemented with $2 \mathrm{mM} \beta$-glycerophosphate (Sigma Chemical Co., St. Louis, MO). The cultures were maintained at $37^{\circ} \mathrm{C}$ in a humidified atmosphere of $5 \% \mathrm{CO}_{2}, 95 \%$ air. Confluent cultures were collected by trypsinization $(0.2 \%$ trypsin and $0.02 \%$ ethylenediamine tetraacetic acid (EDTA)) and subcultured.

\section{Immunohistochemistry on Sections and on Cell Cultures}

Cultured cells were fixed with $70 \%$ ethanol for $1 \mathrm{~h}$ at $4{ }^{\circ} \mathrm{C}$ and permeabilized for 15 min with $0.5 \%$ Triton X-100 in PBS prior to immunohistochemistry. The endogenous peroxidase activity was blocked with $3 \% \mathrm{H}_{2} \mathrm{O}_{2}$ for $5 \mathrm{~min}$. Immunoperoxidase staining on sections and cell cultures were done as previously described [29-30]. Paraffin sections were first deparaffinized, while cryostat sections were immediately exposed to a $0.3 \%$ solution of hydrogen peroxide in methanol and rinsed in PBS. After blocking with PBS containing 1\% bovine serum albumin (BSA), the slides were rinsed in PBS and then incubated overnight at $4{ }^{\circ} \mathrm{C}$ with the anti-Cx43 serum $(2 \mu \mathrm{g} / \mathrm{ml})$ diluted in PBS containing $0.2 \%$ BSA. Secondary antibodies were affinity purified with goat anti-rabbit peroxidase-labeled immunoglobulins. Peroxidase was revealed by incubation with 3-amino-9-ethylcarbazole (AEC) reaction solution and then the slides were mounted with Glycergel (Dako Corporation, Carpinteria, CA).

Controls were performed by omitting the primary antibodies or the utilization of preimmune sera at the same dilution and in the same manner as the connexin 43 antibody.

\section{RESULTS}

After the extraction of the tooth germs, the histological examination showed that they were at the bell stage (Figure 1).

In the canine and central incisor tooth germs of a 17-weekold embryo, weak Cx43 immunostaining was seen in cells of the inner dental epithelium, stellate reticulum and stratum inter-

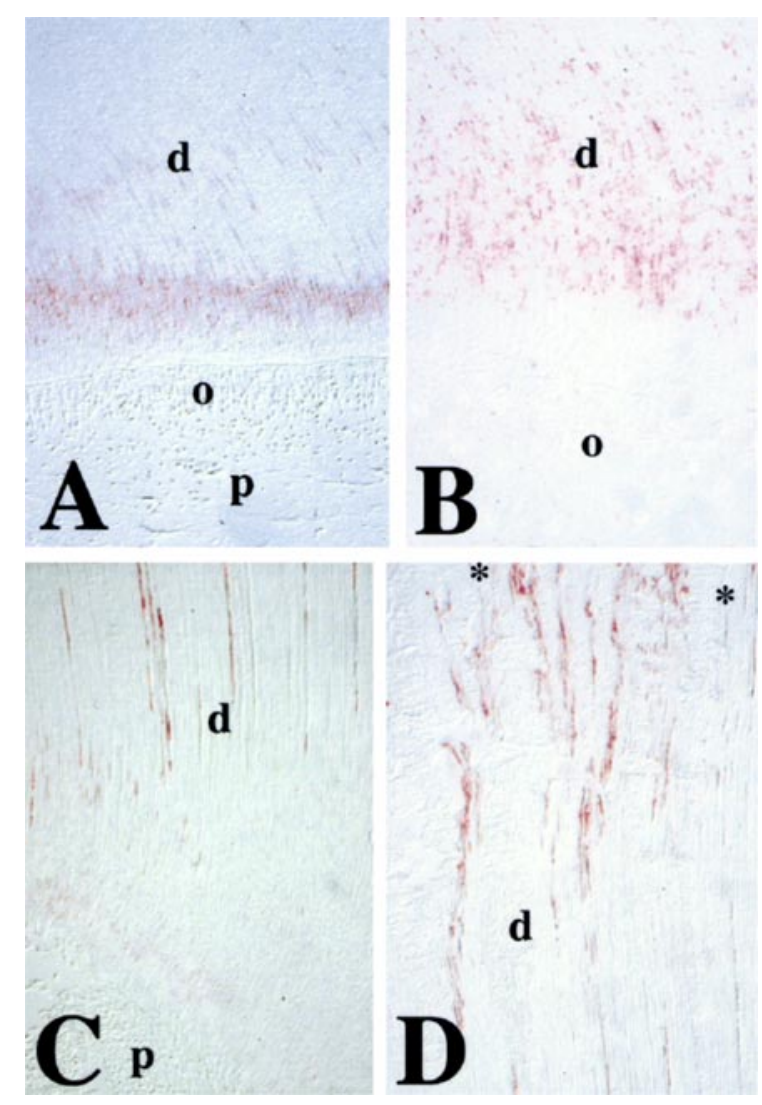

Figure 2. Immunohistochemical localization of $\mathrm{Cx} 43$ in intact and carious permanent human teeth. (A) In intact teeth of a 17-year-old adolescent, $\mathrm{Cx} 43$ immunostaining is detected in the odontoblastic processes; $\times 10$. (B) Higher magnification of (A); $\times 40$. (C) In carious teeth of 40-year-old adults, Cx43 immunoreactivity is detected in odontoblastic processes facing the carious lesion front; $\times 10$. (D) Strong Cx43 immunostaining is found in the odontoblastic processes approching the carious front (asterisks); $\times 10$. Abbreviations: $d$, dentin; o, odontoblasts; p, pulp.

medium. A staining gradient was observed in the inner enamel epithelium from the cervical loop to the cusp region: the cervical loop was negative for $\mathrm{Cx} 43$, while the immunostaining increased toward the cusp region (Figure 1, A-C), where inner enamel epithelial cells differentiate into preameloblasts.

In the first molar of a 22-week-old embryo, Cx43 was detected in the stratum intermedium, stellate reticulum, and preameloblasts. Moreover, Cx43 staining was found in dental mesenchyme and differentiating odontoblasts (Figure 1, D-F).

In the 17-year-old developing third molars, $\mathrm{Cx} 43$ expression was restricted to the odontoblast processes but was not observed in the odontoblast cell bodies (Figure 2, A and B).

Connexin 43 expression in mature intact and carious teeth showed a distinctive pattern. While the labeling was completely absent in mature control samples, $\mathrm{Cx} 43$ immunoreactivity was observed in carious teeth as shown here (see Figure 2, C and D). The labeling was restricted to the cells located in the vicinity of carious lesions. There, $\mathrm{Cx} 43$ was distributed in the processes of mature odontoblasts (Figure 2, C and D). 


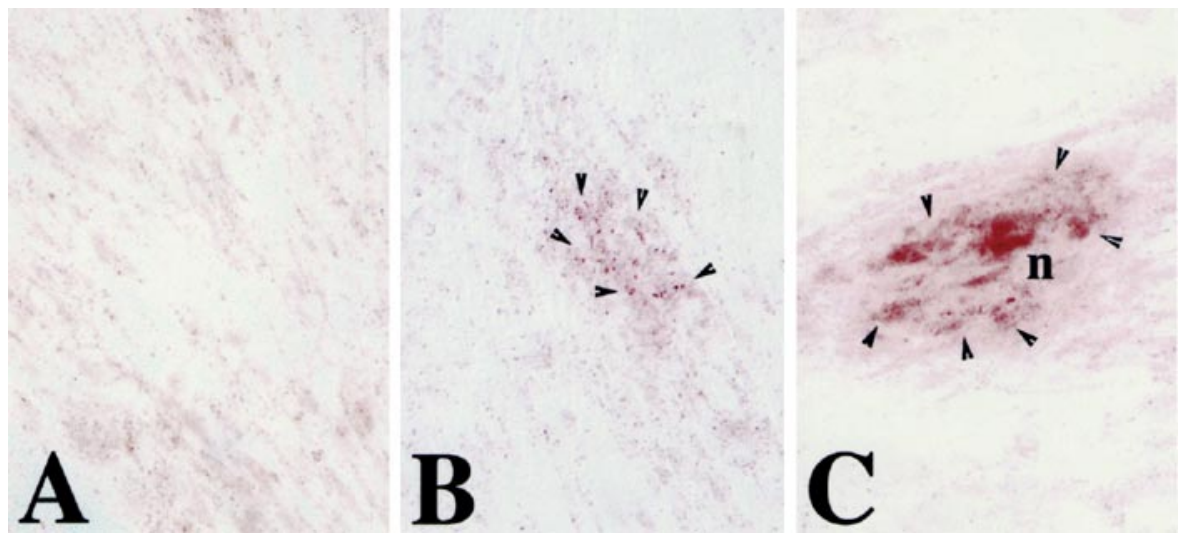

Figure 3. Cx43 immunoreactivity in cultured human dental pulp cells in vitro after $\beta$-glycerophosphate treatment. (A) Weak Cx43 immunostaining is observed in cultures of pulp cells; $\times 20$. (B) Cx 43 labeling is evident in aggregated cells involved in the formation of mineral nodules (arrowheads) $\times 20$. (C) Increased Cx43 immunostaining in cells involved in mineral matrix formation and deposition; $\times 20$. Abbreviation: $\mathrm{n}$, nodule.

\section{Connexin 43 Expression in Human Dental Pulp Cells In Vitro}

This present study was based on an established primary culture of human dental pulp explants where several molecular (collagen I, osteonectin, and nestin) and mineral (Fourier transform infrared microspectroscopic analyses) forms of evidence show the formation of dentin mineralized nodules in vitro (see refs. 29 and 30). Faint $\mathrm{Cx} 43$ immunoreactivity was observed in monolayered pulp cells (Figure 3A), while clear immunolabelling appeared to be associated with aggregated cells during the initial stages of mineralized nodule formation (Figure 3B). Furthermore, $\mathrm{Cx} 43$ labeling was even more clearly evidenced and intense in well-formed mineralized nodules (Figure 3C).

\section{DISCUSSION}

This work shows the distribution of $\mathrm{Cx} 43$ in developing and adult human teeth. During teeth development, $\mathrm{Cx} 43$ is expressed in epithelial cells (i.e., preameloblasts, stratum intermedium, stellate reticulum) and differentiating odontoblasts. These results are in agreement with previous results $[23,24]$ in rodent dental tissues, showing that $\mathrm{Cx} 43$ is expressed in both epithelial and pulp cells. Cx43 expression in dental tissues is correlated to cytodifferentiation gradients. Gradients of $\mathrm{Cx} 43$ expression have been also reported in the developing cardiac muscle [31]. The precise role of gap junctions in such gradients remains unclear, but in the developing teeth, these gradients correspond to the differentiation status of precise dental cell populations.

The interface between the inner enamel epithelium and the dental pulp displays various changes of basement membrane components, such as type IV collagen, laminin, fibronectin, and proteoglycans, at the region of differentiating odontoblasts [32, 33]. In areas where cytodifferentiation starts, the preexisting basement membrane components may be degraded and removed and new components must be deposed. Therefore, the expression of $\mathrm{Cx} 43$ in both pulp and inner enamel epithelial cells and the gradient of $\mathrm{Cx} 43$ toward their differentiated stages may have some role in the differentiation of these cell types.

\section{Cx43 in Developing and Intact Adult Human Teeth}

$\mathrm{Cx} 43$ was upregulated in pulp cells differentiating into odontoblast. $\mathrm{Cx} 43$ was predominantly expressed in the cuspal region of the tooth pulp. Previous studies in cat teeth showed that when the fluorescent lucifer yellow dye was introduced to odontoblasts, some subodontoblastic cells were fluorescent in addition to the odontoblastic cells, indicating that the gap junctions between the odontoblasts and the subodontoblast cells are functional [34]. Cx43 is expressed in the stratum intermedium. Few studies concerning the stratum intermedium are available, and its functional role is not known. It is believed that this layer may be essential to enamel formation, because it is absent in the part of the tooth germ that outlines the root portions of the tooth, but does not form enamel [35]. These data suggest that expression of Cx43 may play a role in both amelogenesis and dentinogenesis of human teeth.

In permanent adolescent teeth, $\mathrm{Cx} 43$ is detected in the odontoblast processes. Ramifications exist between the dentinal tubuli [36], permitting the contact of either odontoblast processes or nerve fibers and odontoblast processes as suggested by Holland [19]. This may indicate that connexins are involved in the direct communication between odontoblasts and/or odontoblasts and nerve fibers. In permanent adult teeth, $\mathrm{Cx} 43$ is downregulated. Since gap junctions are detected in adult human tissues [20,21], this suggests that other connexins are upregulated in adult dental tissues. As a matter of fact, it has been reported that $\mathrm{Cx} 32$ was also expressed in epithelial cells during the late bell stage of rodent tooth development and that Cx26 was expressed in odontoblasts of the adult rat teeth [25].

\section{Cx43 in Irritated Adult Human Teeth}

Microorganisms are involved in both decalcification and proteolysis of the dentin during the process of dental caries. In 
response to this irritation, the secretory activity of the odontoblasts is stimulated to elaborate reactionary dentin [37] and the tubuli become calcified. Cx43 is reexpressed in the processes of odontoblasts surrounding the carious lesion, suggesting a role for $\mathrm{Cx} 43$ in the hypercalcification process.

We have shown recently that dentin can be produced in vitro from cultured human pulp cells [29]. Cx43 is weakly expressed in these cells, but its expression is upregulated during mineralization processes. This is in accordance with previous findings showing increased calcium content of the extracellular matrix and enlarged mineralization nodules in steoblastlike cells transfected with Cx43 cDNA [38]. The fact that $\mathrm{Cx} 43$ is important in mineralization processes has been evidenced by recent data showing that $\mathrm{Cx} 43$ deficiency results in delayed ossification, craniofacial abnormalities, and osteoblast dysfunctions. This is illustrated by the fact that $\mathrm{Cx} 43$-null mice exhibit reduced expression of specific genes and stunted mineralization in vitro, indicating that $\mathrm{Cx} 43$ is involved in osteogenesis and normal osteoblast functions [39]. These results suggest that $\mathrm{Cx} 43$ may also be involved in the secretory activity of odontoblasts in dentin production and mineralization both during tooth development and after dental injury.

In a model system where the rat teeth are forced to move (orthodontic forces), expression of $\mathrm{Cx} 43$ has been shown in osteoclasts and periodontal ligament cells in compression zones, and in osteoblasts and osteocytes in tension zones of the periodontal ligament. These results support the hypothesis that $\mathrm{Cx} 43$ may play a role in the coordination of an alveolar bone remodeling [40]. Cx43 may also play a role in the synchronization of mineral matrix deposition by odontoblasts in human teeth.

In conclusion, Cx43 expression in human dental tissues is correlated with cytodifferentiation and mineralization processes during both normal and pathologic conditions.

\section{ACKNOWLEDGMENTS}

This work was supported by institutional grants from the Université de la Méditerranée. The authors are grateful to Daniel Gros (IBDM, Luminy, Marseille, France) for kindly providing the anti-connexin 43 antibodies.

\section{REFERENCES}

[1] Kumar, N.M., and Gilua, N.B. (1996). The gap junction communication channel. Cell 84:381-388.

[2] Goodenough, D.A., Goliger, J.A., and Paul, D.L. (1996). Connexins, connexons, and intercellular communication. Annu. Rev. Biochem. 65:475502 .

[3] Lowenstein, W.R. (1981). Junctional intercellular communication: The cell to cell membrane channel. Physiol. Rev. 61:829-913.

[4] Mehta, P., Bertram, J., and Lowenstein, W.R. (1986). Growth inhibition of transformed cells correlates with normal cells. Cell 44:187196.

[5] Guthrie, S.C., and Gilula, N.B. (1989). Gap junctional communication and development. Trends Neurosci. 12:12-16.

[6] Ruangvoravat, C.P., and Lo, C.W. (1992). Connexin43 expression in the mouse embryo: Localization of transcripts within developmentally significant domains. Dev. Dyn. 194:261-281.
[7] Lo, C.W. (1996). The role of gap junction membrane channels in development. J. Bioenerg. Biomembr. 28(4):379-385.

[8] Warner, A.E., Guthrie, S.C., and Gilula, N.B. (1984). Antibodies to gap junctional proteins selectively disrupts junctional communication in an early amphibian embryo. Nature 311:127-131.

[9] Fraser, S.E., Green, C.R., Bode, H.R., and Gilula, N.B. (1987). Selective disruption of gap junctional communication interferes with a patterning process in hydra. Science 237:49-55.

[10] Bevilacqua, A., Loch-Caruso, R., and Erickson, R. (1989). Abnormal development and dye coupling produced by antisense RNA to gap junction protein in mouse preimplantation embryo. Proc. Natl. Acad. Sci. USA 86:5444-5448.

[11] Lee, S., Gilula, N.B., and Warner, A.E. (1987). Gap junctional communication and compaction during preimplantation stages of mouse development. Cell 51:851-860.

[12] Reaume, A.G., de Sousa, P.A., Kulkarni, S., Langille, B.L., Zhu, D., Davies, T.C., Juneja, S.C., Kidder, G.M., and Rossant, J. (1995). Cardiac malformation in neonatal mice lacking connexin43. Science 267(5205):1831-1834.

[13] Kollar, E.J., and Lumsden, A.G.S. (1979). Tooth morphogenesis: The role of the innervation during induction and pattern formation. J. Biol. Buccale 7:49-60.

[14] Ten Cate, A.R. (1989). Oral Histology, Development, Structure and Function, 3rd ed. (C. V. Mosby, St. Louis, MO).

[15] Stock, D.W., Weiss, K.M., and Zhao, Z. (1997). Patterning of the mammalian dentition in development and evolution. Bioessays 19:481490.

[16] Garant, P.R. (1972). The demonstration of complex gap junctions between the cells of the enamel organ with lanthanum nitrate. J. Ultrastruct. Res. 40:333-348.

[17] Sasaki, T., Higashi, S., Tachikawa, T., and Yoshiki, S. (1981). Morphogenesis of gap junctions in rat amelogenesis. J. Electron Microsc. 30:191197.

[18] Goldberg, M., Escaig, F., and Septier, D. (1981). Etude par cryofracture et sur coupes fines des jonctions intercellulaires entre les odontoblastes de l'incisive de rat. Modifications induites par la vinblastine. J. Biol. Buccale 9:141-153.

[19] Holland, G.R. (1987). The effect of nerve section on the incidence and distribution of gap junctions in the odontoblast layer of the cat. Anat. Rec. 218:458-465.

[20] Koling, A., and Rask-Andersen, H. (1984). Membrane junctions between odontoblasts and associated cells. Acta Odontol. Scand. 42:1322.

[21] Calle, A. (1985). Intercellular junctions between human odontoblasts. Acta Anat. 122:138-144.

[22] Koling, A., Rask-Andersen, H., and Gagger-Sjoback, D. (1981). Membrane junctions on odontoblasts: A freeze-fracture study. Acta Odontol. Scand. 39:355-360.

[23] Pinero, G.J., Parker, S., Rundus, V., Hertzbeg, E.L., and Minkoff, R. (1994). Immunolocalization of connexin 43 in the tooth germ of the neonatal rat. Histochem. J. 26:765-770.

[24] Kagayama, M., Akita, H., and Sasano, Y. (1995). Immunohistochemical localization of connexin 43 in the developing tooth germ of rat. Anat. Embryol. 191:561-568.

[25] Fried, K., Mitsiadis, T.A., Guerrier, A., Haegerstrand, A., and Meister, B. (1996). Combinatorial expression patterns of the connexins 26, 32 and 43 during development, homeostasis, and regeneration of rat teeth. Int. J. Dev. Biol. 40:985-995.

[26] El Aoumari, A., Fromaget, C., Dupont, E., Reggio, H., Durbec, P., Briand, J.P., Boller, K., Kreitman, B., and Gros, D. (1990). Conservation of a cytoplasmic carboxy-terminal domain of connexin 43, a gap junctional protein, in mammal heart and brain. J. Membr. Biol. 115(3):229240.

[27] Giaume, C., Fromaget, C., el Aoumari, A., Cordier, J., Glowinski, J., and Gros, D. (1991). Gap junctions in cultured astrocytes: Single-channel 
currents and characterization of channel-forming protein. Neuron 6(1):133-143.

[28] Bastide, B., Jarry-Guichard, T., Briand, J.P., Deleze, J., and Gros, D. (1996). Effect of antipeptide antibodies directed against three domains of connexin43 on the gap junctional permeability of cultured heart cells. J. Membr. Biol. 150(3):243-253.

[29] About, I., Bottero, M.-J., De Denato, P., Camps, J., Franquin, J.-C., and Mitsiadis, T.A. (2000). Human dentin production in vitro. Exp. Cell Res. 258:33-41.

[30] About, I., Laurent-Maquin, D., Lendahl, U., and Mitsiadis, T.A. (2000). Nestin expression in embryonic and adult human teeth under normal and pathological conditions. Am. J. Pathol. 157:287-295.

[31] Fromaget, C., El Aoumari, A., and Gros, D. (1992). Distribution pattern of connexin 43, a gap junctional protein, during the differentiation of mouse heart myocytes. Differentiation 51:9-20.

[32] Thesleff, I., Barrack, H.J., Foidart, J.M., Vaheri, A., Pratt, R.M., and Martin, G.R. (1981). Changes in the distribution of type IV collagen, laminin, proteoglycan, and fibronectin during mouse tooth development. Dev. Biol. 81:182-192.

[33] McCollum, M.A., and Sharpe, P.T. (2001). Developmental genetics and early hominid craniodental evolution. Bioessays 23:481-493.
[34] Ushiyama, J. (1989). Gap junctions between odontoblasts revealed by transjunctional flux of fluorescent tracers. Cell Tissue Res. 258:611-616.

[35] Bhussry, B.R. (1980). "Development and growth of teeth." In: Orban's Oral Histology and Embryology, S.N. Bhaskar (ed.), pp. 24-45. (Mosby, London).

[36] Mjör, I.A., and Nordahl, I. (1996). The density and branching of dentinal tubules in human teeth. Arch. Oral Biol. 41:401-412.

[37] Tziafas, D., Smith, A.J., and Lesot, H. (2000). Designing new treatment strategies in vital pulp therapy. J. Dent. 28:77-92.

[38] Gramsch, B., Gabriel, H.D., Wiemann, M., Grummer, R., Winterhager, E., Bingmann, D., and Schirrmacher, K. (2001). Enhancement of connexin 43 expression increases proliferation and differentiation of an osteoblast-like cell line. Exp. Cell Res. 264:397-407.

[39] Lecanda, F., Warlow, P.M., Sheikh, S., Furlan, F., Steinberg, T.H., and Civitelli, R. (2000). Connexin43 deficiency causes delayed ossification, craniofacial abnormalities, and osteoblast dysfunction. J. Cell Biol. 151:931-944.

[40] Su, M., Borke, J.L., Donahue, H.J., Li, Z., Warshawsky, N.M., Russell, C.M., and Lewis, J.E. (1997). Expression of connexin 43 in rat mandibular bone and periodontal ligament (PDL) cells during experimental tooth movement. J. Dent. Res. 76:1357-1366. 